\title{
Validation of a New Cycle Ergometer
}

\author{
Authors \\ M. F. Glaner, R. A. S. Silva \\ Affiliation \\ UNIEURO University Center, Physical Education, Brasília, Brazil
}

\section{Key words \\ - accuracy \\ - cycling \\ - calibration \\ - testing \\ - ergometry}

accepted after revision October 24, 2010

Bibliography DOI http://dx.doi.org/ 10.1055/s-0030-1268490 Published online: December 16, 2010 Int J Sports Med 2011; 32: 117-121 @ Georg Thieme Verlag KG Stuttgart · New York ISSN 0172-4622

\section{Correspondence}

Maria Fátima Glaner, PhD Quadra 201

Lote 6 Bloco B - apt. 803

Águas Claras

71937-540 Brasília

Brazil

Tel.: + 55/61/33569000

Fax: $+55 / 61 / 33563010$

mfglaner@gmail.com

\section{Abstract \\ $\nabla$}

The purpose of this study was to test the concurrent validity of the ICBE compared to the Monark $^{\circledR}$ cycle ergometer by indirect dynamic calibration. 42 men were randomly submitted to 2 maximal stress tests with increments of $50 \mathrm{~W}$ at 2-min intervals. One test was performed on the Monark ${ }^{\circledR}$ bicycle $(834 / E)$ and the other on the ICBE. Cardiovascular, perceived exertion and hemodynamic responses were compared between the 2 bicycles. No differences $(p>0.05)$ were observed in resting heart rate (HR), maximum HR, peak oxygen uptake $\left(\mathrm{VO}_{2 \mathrm{P}}\right.$ $\mathrm{L} \cdot \mathrm{min}^{-1}$ and $\left.\mathrm{VO}_{2 \mathrm{p}} \mathrm{mL} \cdot \mathrm{kg}^{-1} \cdot \mathrm{min}^{-1}\right)$, and number of stages completed. High correlations $(r>0.85)$ were found between $\mathrm{HR}$ and $\mathrm{VO}_{2 \mathrm{P}}$. Residual

\section{Introduction}

$\nabla$

Cardiopulmonary stress tests have been used during Spinning ${ }^{\circledR}$ classes or sessions to determine differences in cardiovascular, hemodynamic and perceived exertion $[5,13,14]$. In those studies Spinning ${ }^{\circledR}$ bicycles were used as ergometers. However, most models of Spinning ${ }^{\circledR}$ bicycles do not permit a precise workload adjustment. As a consequence, the use of these bicycles in cardiopulmonary stress tests is limited since the results will not be accurate. To overcome this limitation, an indoor cycling bicycle ergometer (ICBE) was constructed and its fragmented calibration was determined [25]. The direct and indirect dynamic calibration of the ICBE has not been established.

The ICBE possesses the same characteristics as Spinning ${ }^{\circledR}$ bicycles, but permits the gradual adjustment of workload through the power produced by subject (power $=$ force $\mathrm{x}$ speed) [27]. The ICBE [25] consists of a frame similar to that of Spinning ${ }^{\circledR}$ bicycles but uses the loading system analysis indicated strong agreement between the 2 cycle ergometers in terms of $\mathrm{VO}_{2 \mathrm{P}} \mathrm{L} \cdot \mathrm{min}^{-1}$ $[-0.36-0.30]$ and $\mathrm{VO}_{2 \mathrm{P}} \mathrm{mL} \cdot \mathrm{kg}^{-1} \cdot \mathrm{min}^{-1}[-4.98-$ 4.46]. Residual dispersion ( $\mathrm{r}=0.25$ for both) showed that the mathematical differences in $\mathrm{VO}_{2 \mathrm{P}} \mathrm{L} \cdot \mathrm{min}^{-1}$ and $\mathrm{VO}_{2 \mathrm{P}} \mathrm{mL} \cdot \mathrm{kg}^{-1} \cdot \mathrm{min}^{-1}$ between cycle ergometers were independent. The correlation coefficient ( $r$ ) and coefficient of determination $\left(R^{2}\right)$ between $\mathrm{VO}_{2 \mathrm{P}} \mathrm{L} \cdot \mathrm{min}^{-1}(\mathrm{r}=0.90$; $\left.\mathrm{R}^{2}=0.80\right)$ and $\mathrm{VO}_{2 \mathrm{P}} \mathrm{mL} \cdot \mathrm{kg}^{-1} \cdot \mathrm{min}^{-1} \quad(\mathrm{r}=0.90$; $\mathrm{R}^{2}=0.81$ ) obtained for the 2 cycle ergometers were high, whereas the standard error of the estimate was low $\left(0.186 \mathrm{~L} \cdot \mathrm{min}^{-1}\right.$ and $2.56 \mathrm{~mL}$. $\mathrm{kg}^{-1} \cdot \mathrm{min}^{-1}$, respectively). The ICBE presents concurrent validity for use in submaximal and maximal cardiopulmonary tests.

from a Monark $^{\circledR}$ cycle ergometer (basket of weights). The final model ( $\bullet$ Fig. 1 ) measures $104 \mathrm{~cm}$ in length and $51 \mathrm{~cm}$ in width, weighs $38 \mathrm{~kg}$, and has a mechanical type brake, fixed gear, seat tube angle of $72^{\circ}$, and a basket of $500-\mathrm{g}$ and $250-1000-g$ weights. It possesses fragmented calibration of the wheel and a resistive mechanical load. A Cat-Eye ${ }^{\circledR}$ bicycle computer was installed to measure speed and cadence. It remains unknown whether the ICBE presents concurrent validity for use in cardiopulmonary tests when compared to a gold standard cycle ergometer. Therefore, the indirect dynamic calibration was used in the present study to test the concurrent validity of the ICBE compared to a Monark $^{\circledR}$ cycle ergometer. The hypothesis was that subjects present similar cardiovascular, perceived exertion and hemodynamic responses to exercise on the 2 cycle ergometers. 


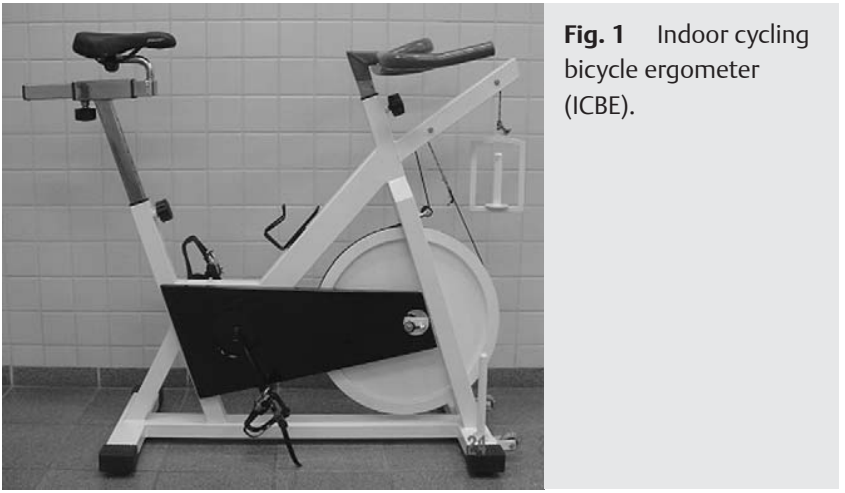

Material and Methods

$\nabla$

Subjects

The sample consisted of 42 amateur male cyclists of regional level. Excluded were subjects who presented resting electrocardiogram and blood pressure anomalies, subjects who reported any problem that would impair their participation in the cardiopulmonary tests, and subjects practicing cycling $<1$ year. The study has been performed in accordance with the ethical standards of the IJSM [8] and was approved by the Ethics Committee of the Catholic University of Brasília.

\section{Protocol}

\section{Pre-test assessment}

The subjects were submitted to anamnesis to evaluate the presence of some type of health condition that would restrict their participation in the cardiopulmonary tests. Demographic and periodic data and training volume were collected. After a 10min rest, blood pressure was measured with a mercury column sphygmomanometer (WanRoss ${ }^{\circledR}$ ) and stethoscope (WelchAllyn ${ }^{\circledR}$ ). Next, a resting electrocardiogram was obtained (Marquette Hellige CardioSmart ${ }^{\circledR}$ ).

\section{Anthropometry}

Body weight, height (Filizola Personal Line ${ }^{\circledR}$ ), and the sum of 7 skinfolds (Lange caliper ${ }^{\circledR}$ ) were determined to characterize the sample. Pubic symphysis height was measured (Seca) to adjust the seat to the subject [4]. Body density was estimated using the equation for 7 skinfolds [22] and converted into relative body fat percentage (\%fat) by the equation of Siri [26].

\section{Cardiopulmonary test}

Before each test, the 2 cycle ergometers (Monark ${ }^{\circledR}$ and ICBE) were adjusted to each subject considering angular measurements of thigh/trunk and trunk/arm segments (Cardiomed ${ }^{\circledR}$ goniometer) and pubic symphysis height. The pedal clips of each subject were attached to the cycle ergometers.

Each subject underwent the same cardiopulmonary test twice at an interval of 48-96h, once on a Monark ${ }^{\circledR} 834 \mathrm{E}$ cycle ergometer and once on the ICBE. The tests were randomized and performed at similar times. The room temperature was controlled at $18^{\circ}$ to $22^{\circ} \mathrm{C}$. The subjects were asked to maintain the same level of physical effort on the days preceding the 2 tests.

In view of the characteristics of the subjects studied, warm-up consisted of $1 \mathrm{~min}$ at the initial load. The initial load was $50 \mathrm{~W}$, with increments of $50 \mathrm{~W}$ at intervals of $2 \mathrm{~min}$ (Balke protocol). Cadence was maintained at $50 \mathrm{rpm}$ (Qwik Time ${ }^{\circledR}$ QT-3 metronome) to minimize the variability in power produced at each stage. Low pedaling rates (50-60 rpm) are more economical and efficient than the high pedaling rate (>90 rpm) [15]. There are no differences in delta efficiency for different cadences ranging from 50 to $100 \mathrm{rpm}$ for runners, less trained non-cyclists or trained cyclists [18]. The tests were performed until voluntary exhaustion. The last stage was considered to be completed after a minimum exercise period of $1 \mathrm{~min} 40 \mathrm{~s}$. The subjects remained seated on the saddle during the tests.

Absolute and relative oxygen uptake $\left(\mathrm{VO}_{2} \mathrm{~L} \cdot \mathrm{min}^{-1} ; \mathrm{VO}_{2} \mathrm{ml} \cdot \mathrm{kg}^{-1}\right.$. $\mathrm{min}^{-1}$, respectively) were obtained breath-by-breath and were expressed as the mean value of the last $20 \mathrm{~s}$ of each stage and after 2 min of recovery. Peak oxygen uptake $\left(\mathrm{VO}_{2 \mathrm{P}}\right)$ was defined as the highest value obtained in the last stage completed and these were also computed (n stage). The gases were analyzed with an open-circuit gas analysis system (Metalyzer $3 \mathrm{~B}^{\circledR}$, Cortex Biophysics) using the Metasoft 3.3 and Ergo PC Elite 3.3 dedicated softwares (Micromed) [16]. The analyzer was calibrated before each test using gases of known concentration $\left(17 \% \mathrm{O}_{2}\right.$ and $5 \% \mathrm{CO}_{2}$ ) and a 3-liter syringe.

Were also obtained resting heart rate (RHR), heart rate (HR) measured at the end of each stage and 2 min after recovery and maximum $\mathrm{HR}\left(\mathrm{HR}_{\max }\right)$ measured at the end of the last stage completed were also obtained (CM5, Micromed ${ }^{\circledR}$ Digital Electrocardiograph).

\section{Perceived exertion}

Perceived exertion (PE) was rated on a 6-20 point Borg scale at the end of each stage and 2 min after recovery.

\section{$\mathrm{VO}_{2}$ cut-off}

There is a lack of consistency between studies as to the level of error that is deemed to be acceptable [12]. The variation in $\mathrm{VO}_{2 \max }$ between different gas analysis systems should not exceed $4 \%$ or $2-3 \mathrm{~mL} \cdot \mathrm{kg}^{-1} \cdot \mathrm{min}^{-1}[1]$. This affirmation is not clear: $3 \mathrm{~mL}$. $\mathrm{kg}^{-1} \cdot \mathrm{min}^{-1}$ corresponds to $4.28 \%$ for $\mathrm{VO}_{2 \max }=70 \mathrm{~mL} \cdot \mathrm{kg}^{-1} \cdot \mathrm{min}^{-1}$, but to $7.5 \%$ for $\mathrm{VO}_{2 \max }=40 \mathrm{~mL} \cdot \mathrm{kg}^{-1} \cdot \mathrm{min}^{-1}$. Differences in $\mathrm{VO}_{2}$ and $\mathrm{VO}_{2 \max }$ of $5-10 \mathrm{~mL} \cdot \mathrm{kg}^{-1} \cdot \mathrm{min}^{-1}(10-15 \%)$ between 3 gas analysis systems have been reported for submaximal and maximal workloads [1]. Analysis of the repeatability of $\mathrm{VO}_{2}$ measurement showed a difference of up to $15 \%$ between the same 3 analyzers and between different laboratories [29]. Differences of $22 \%$ have been reported when comparing 3 gas analysis systems [11]. These results show that a measurement error of $<5 \%$ is not an easily achievable goal and acceptable limits in predictive validity for measurements of $\mathrm{VO}_{2}$ is poorly defined [12]. Using the findings of these studies as a parameter, an acceptable error $\leq 8 \%$ was established for $\mathrm{VO}_{2}$, corresponding to approximately half the difference observed when comparing the same 3 analyzers [29]. This value is also lower than the tolerable error for the same gas analysis system [12] and lower than the difference in $\mathrm{VO}_{2 \max }$ obtained for the same cycle ergometer. Thus, $8 \%$ of $\mathrm{VO}_{2}\left(50.25 \mathrm{~mL} \cdot \mathrm{kg}^{-1}\right.$. $\mathrm{min}^{-1}$ and 3.66 L.min ${ }^{-1}$ ) obtained (Mon$\operatorname{ark}^{\circledR}$ ) for the sample of the present study, respectively, correspond to $4 \mathrm{~mL} \cdot \mathrm{kg}^{-1} \cdot \mathrm{min}^{-1}$ and $0.291 \mathrm{~L} \cdot \mathrm{min}^{-1}$. A cut-off value $\leq 8 \%\left(4 \mathrm{~mL} \cdot \mathrm{kg}^{-1} \cdot \mathrm{min}^{-1} ; 0.291 \mathrm{~L} \cdot \mathrm{min}^{-1}\right)$ was used for analysis of individual variations (residue analysis), whereas a cut-off $\leq 5 \%$ (2.51 mL. $\mathrm{kg}^{-1} \cdot \mathrm{min}^{-1} ; 0.183 \mathrm{~L} \cdot \mathrm{min}^{-1}$ ) was used for mean random error and standard error of the estimate.

\section{Statistical analysis}

The data showed a normal distribution (Shapiro-Wilk test) and are reported as means \pm standard deviation. To determine 


$\begin{array}{lccccc}\text { Variables } & \text { Monark }^{\circledR} & \text { ICBE } & \mathbf{t} & \mathbf{p} & \mathbf{r} \\ \mathrm{RHR}_{\mathrm{b} \cdot \min }{ }^{-1} & 56.8 \pm 12.3 & 57.6 \pm 11.9 & 0.751 & 0.457 & 0.853 \\ \mathrm{HR}_{\operatorname{max~b.min}}-1 & 182.1 \pm 12.4 & 180.6 \pm 12.6 & -1.558 & 0.127 & 0.879 \\ \mathrm{VO}_{2 \mathrm{PL} \cdot \mathrm{min}^{-1}} & 3.66 \pm 0.41 & 3.68 \pm 0.41 & 0.550 & 0.585 & 0.896 \\ \mathrm{VO}_{2 \mathrm{PL} \cdot \mathrm{kg}^{-1} \cdot \mathrm{min}^{-1}} & 50.3 \pm 5.8 & 50.5 \pm 5.7 & 0.568 & 0.573 & 0.899\end{array}$

Table 1 Comparison of heart rate $(\mathrm{HR})$ and maximal oxygen uptake $\left(\mathrm{VO}_{2 \mathrm{P}}\right)$ between the 2 cycle ergometers.

Note: $t=$ paired $t$-test, $p=$ level of significance (t-test), $r=$ Pearson's correlation coefficient, $R H R=$ resting heart rate, $H R_{\max }=m a x i m u m$ heart rate
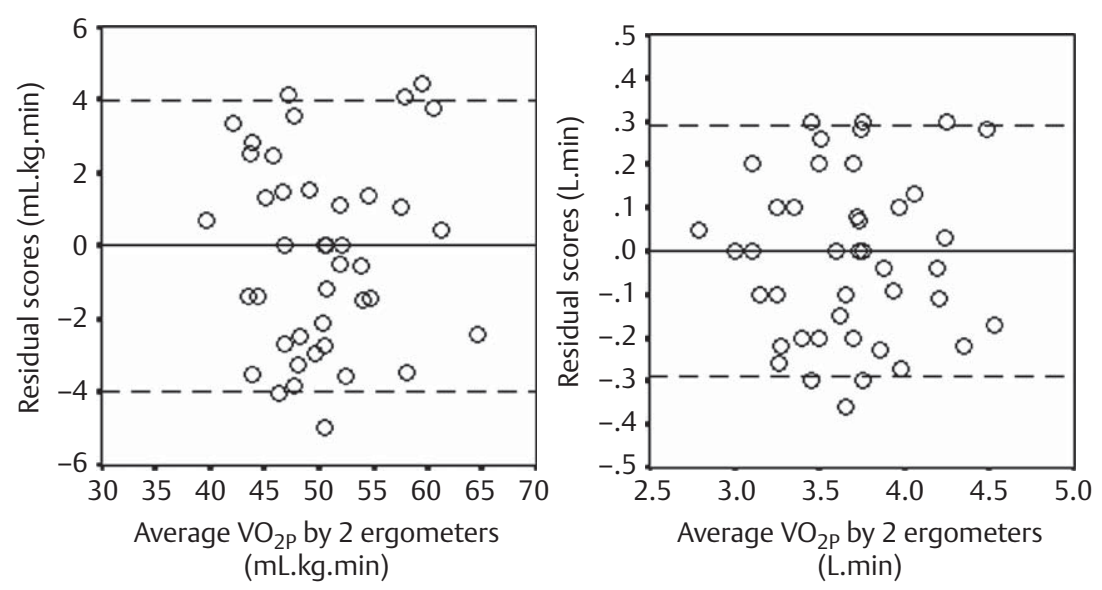

Fig. 2 Analysis of residual scores of peak oxygen consumption obtained for the Monark ${ }^{\circledR}$ cycle ergometer and ICBE. The upper and lower dashed lines represent the validation limits of the ICBE $\left(\mathrm{VO}_{2 \mathrm{P}}=0.291 \mathrm{~L} \cdot \mathrm{min}^{-1}\right.$ and $\left.4.0 \mathrm{~mL} \cdot \mathrm{kg}^{-1} \cdot \mathrm{min}^{-1}\right)$.

whether the ICBE presented indirect dynamic calibration compared to the Monark ${ }^{\circledR}$ cycle ergometer, the cardiopulmonary, hemodynamic and perceived exertion variables obtained in the tests performed on the 2 cycle ergometers were compared using the paired t-test $(p>0.05)$, Pearson's correlation coefficient $(r)$, standard error of the estimate (SEE), coefficient of determination $\left(\mathrm{R}^{2}\right)(\mathrm{p} \leq 0.05)$, and analysis of residual scores [3]. The mean random error of $\mathrm{VO}_{2}\left(\Delta \%=\left[\Sigma\left(\mathrm{VO}_{2}\right.\right.\right.$ Monark $-\mathrm{VO}_{2}$ ICBE $\left.) / 10\right]$ was also determined. Statistical analysis was performed using the Statistical Package for the Social Sciences, v. 14.0, licensed for use to the Catholic University of Brasília.

\section{Results}

$\nabla$

The sample presented the following characteristics (mean \pm standard deviation): age $=34 \pm 8$ years; height $=175 \pm 6 \mathrm{~cm}$; body weight $=73 \pm 6 \mathrm{~kg}$; $\% \mathrm{fat}=16 \pm 4$; systolic blood pressure $=117 \pm$ $13 \mathrm{mmHg}$; diastolic blood pressure $=74 \pm 10 \mathrm{mmHg}$; cycling experience $=10 \pm 8$ years; weekly training volume $=332 \pm 160 \mathrm{~km}$, and annual training volume $=10309 \pm 7792 \mathrm{~km}$.

No significant differences $(\mathrm{p}>0.05)$ in $\mathrm{RHR}, \mathrm{HR}_{\mathrm{max}}, \mathrm{VO}_{2 \mathrm{P}} \mathrm{L} \cdot \mathrm{min}^{-1}$, or $\mathrm{VO}_{2 \mathrm{p}} \mathrm{mL} \cdot \mathrm{kg}^{-1} \cdot \mathrm{min}^{-1}$ were observed. The correlations between $\mathrm{HR}$ and $\mathrm{VO}_{2 \mathrm{P}}$ were high $(\mathrm{r}>0.85)$ ( $\diamond$ Table 1$)$. Mean $\mathrm{n}$ stage did not differ between the 2 ergometers [ $\mathrm{t}(41)=0.000 ; 1.0$ ].

Residual analysis, illustrated in $\odot$ Fig. 2, indicates strong agreement between the 2 cycle ergometers in terms of $\mathrm{VO}_{2 \mathrm{P}} \mathrm{L} \cdot \mathrm{min}^{-1}$ [ -0.36-0.30] and $\mathrm{VO}_{2 \mathrm{P}} \mathrm{mL} \cdot \mathrm{kg}^{-1} \cdot \mathrm{min}^{-1}[-4.98-4.46]$, taking the cut-off points established as parameter. Interestingly, $\mathrm{VO}_{2 \mathrm{P}}$ $\mathrm{L} \cdot \mathrm{min}^{-1}$ and $\mathrm{VO}_{2 \mathrm{P}} \mathrm{mL} \cdot \mathrm{kg}^{-1} \cdot \mathrm{min}^{-1}$ obtained for the ICBE differed more than $0.219 \mathrm{~L} \cdot \mathrm{min}^{-1}$ and $4 \mathrm{~mL} \cdot \mathrm{kg}^{-1} \cdot \mathrm{min}^{-1}$ from the Monark $^{\circledR}$ bicycle in 6 of $42(15 \%)$ and 4 of 42 (10\%) subjects, respectively. Residual dispersion ( $r=0.25$ for both) showed that the mathematical differences in $\mathrm{VO}_{2 \mathrm{P}} \mathrm{L} \cdot \mathrm{min}^{-1}$ and $\mathrm{VO}_{2 \mathrm{P}}$ $\mathrm{mL} \cdot \mathrm{kg}^{-1} \cdot \mathrm{min}^{-1}$ between cycle ergometers were independent. The correlation and coefficient of determination between $\mathrm{VO}_{2} \mathrm{P}$
$\mathrm{L} \cdot \mathrm{min}^{-1}\left(\mathrm{r}=0.90 ; \mathrm{R}^{2}=0.80\right)$ and $\mathrm{VO}_{2 \mathrm{P}} \mathrm{mL} \cdot \mathrm{kg}^{-1} \cdot \mathrm{min}^{-1}(\mathrm{r}=0.90$; $\mathrm{R}^{2}=0.81$ ) obtained for the 2 cycle ergometers were high, whereas the SEE was similar to the cut-off points $\left(0.186 \mathrm{~L} \cdot \mathrm{min}^{-1}\right.$ and $2.56 \mathrm{~mL} \cdot \mathrm{kg}^{-1} \cdot \mathrm{min}^{-1}$, respectively).

The comparison of cardiopulmonary, hemodynamic and perceived exertion variables (ICBE vs. Monark ${ }^{\circledR}$ ) is shown in ๑ Table 2. 37 of the 42 subjects reached exhaustion by stage 10 . Four reached stage 11 and 1 stage 13 . Results past stage 10 were excluded in accordance to a similar study by Basset et al. [2]. Differences $(\mathrm{p} \leq 0.05)$ in $\mathrm{VO}_{2} \mathrm{~L} \cdot \mathrm{min}^{-1}$ and $\mathrm{VO}_{2} \mathrm{~mL} \cdot \mathrm{kg}^{-1} \cdot \mathrm{min}^{-1}$ were observed in the $2^{\text {nd }}, 9^{\text {th }}$ and $10^{\text {th }}$ stages, with $\Delta \%$ of $3.5 \pm 1.8 \%$ [1.32-6.66] for $\mathrm{VO}_{2} \mathrm{~L} \cdot \mathrm{min}^{-1}$ and of $3.5 \pm 1.7 \%$ [1.44-6.9] for $\mathrm{VO}_{2} \mathrm{~mL} \cdot \mathrm{kg}^{-1} \cdot \mathrm{min}^{-1}$. Differences $(\mathrm{p} \leq 0.05)$ in HR were observed in the $10^{\text {th }}$ stage and differences in PE in the $10^{\text {th }}$ stage and during recovery.

\section{Discussion}

$\nabla$

The objective of this study was to determine the concurrent validity of the ICBE using indirect dynamic calibration. The RHR results suggested that the subjects started the 2 tests (Monark ${ }^{\circledR}$ and ICBE) under the same fisiological conditions. $\mathrm{HR}_{\max }$ and the HR determined at each stage indicate that cardiovascular stress was similar in the 2 tests. These results are confirmed by lactatemia (data not shown). The same $\mathrm{n}$ stage necessary to complete the tests supports this finding and demonstrates that the power produced by the subjects was similar in ICBE and Monark ${ }^{\circledR}$ cycle ergometer. However, direct dynamic calibration may support these findings. $\mathrm{VO}_{2 \mathrm{P}} \mathrm{L} \cdot \mathrm{min}^{-1}$ and $\mathrm{VO}_{2 \mathrm{P}} \mathrm{mL} \cdot \mathrm{kg}^{-1} \cdot \mathrm{min}^{-1}$ obtained with the ICBE were accurate when compared to those obtained with the Monark $^{\circledR}$ cycle ergometer. This was supported by analysis residual scores, with the observation of strong agreement using a rigorous cut-off point. More than $80 \%$ of the variation in $\mathrm{VO}_{2 \mathrm{P}} \mathrm{L} \cdot \mathrm{min}^{-1}$ and $\mathrm{VO}_{2 \mathrm{P}} \mathrm{mL} \cdot \mathrm{kg}^{-1} \cdot \mathrm{min}^{-1}$ observed for the ICBE was explained by the respective results obtained with the Monark ${ }^{\circledR}$ cycle 
Table 2 Comparison of oxygen uptake $\left(\mathrm{VO}_{2}\right)$, perceived exertion and heart rate between the 2 cycle ergometer according to stage.

\begin{tabular}{|c|c|c|c|c|c|c|c|c|c|}
\hline \multirow[t]{2}{*}{ St. } & \multirow[t]{2}{*}{$\mathbf{n}$} & \multicolumn{2}{|c|}{$\mathrm{VO}_{2 \mathrm{~L} / \min ^{-1}}$} & \multicolumn{2}{|c|}{$\mathrm{VO}_{2 \mathrm{~mL} \cdot \mathrm{kg}^{-1} \cdot \min }{ }^{-1}$} & \multicolumn{2}{|c|}{ Perceived exertion } & \multicolumn{2}{|c|}{ Heart rate b.min -1} \\
\hline & & Monark $^{\circledR}$ & ICBE & Monark $^{\circledR}$ & ICBE & Monark $^{\circledR}$ & ICBE & Monark $^{\circledR}$ & ICBE \\
\hline $1^{\circ}$ & 42 & $0.85 \pm 0.10$ & $0.83 \pm 0.16$ & $11.7 \pm 1.5$ & $11.3 \pm 2.2$ & $6.6 \pm 0.9$ & $6.5 \pm 1.1$ & $83.9 \pm 11.1$ & $83.6 \pm 14.9$ \\
\hline $2^{\circ}$ & 42 & $1.20 \pm 0.17$ & $1.12 \pm 0.21^{*}$ & $16.5 \pm 2.4$ & $15.4 \pm 3.0^{*}$ & $7.5 \pm 1.5$ & $7.2 \pm 1.5$ & $96.3 \pm 13.4$ & $94.0 \pm 14.7$ \\
\hline $3^{\circ}$ & 42 & $1.54 \pm 0.17$ & $1.46 \pm 0.28$ & $21.1 \pm 2.7$ & $20.1 \pm 4.0$ & $8.9 \pm 1.7$ & $8.5 \pm 1.7$ & $108.5 \pm 14.0$ & $106.1 \pm 15.8$ \\
\hline $4^{\circ}$ & 42 & $1.91 \pm 0.22$ & $1.83 \pm 0.36$ & $26.2 \pm 3.7$ & $25.2 \pm 5.2$ & $10.4 \pm 2.0$ & $10.0 \pm 2.0$ & $121.7 \pm 16.2$ & $119.1 \pm 16.9$ \\
\hline $5^{\circ}$ & 42 & $2.26 \pm 0.21$ & $2.23 \pm 0.40$ & $31.2 \pm 4.2$ & $30.7 \pm 5.9$ & $12.0 \pm 2.1$ & $11.5 \pm 2.4$ & $133.8 \pm 16.3$ & $132.1 \pm 18.5$ \\
\hline $6^{\circ}$ & 42 & $2.66 \pm 0.22$ & $2.62 \pm 0.43$ & $36.7 \pm 4.5$ & $36.1 \pm 6.5$ & $13.4 \pm 2.2$ & $13.1 \pm 2.6$ & $146.4 \pm 17.0$ & $144.6 \pm 18.9$ \\
\hline $7^{\circ}$ & 42 & $3.02 \pm 0.22$ & $2.96 \pm 0.39$ & $41.5 \pm 4.7$ & $40.8 \pm 6.5$ & $14.6 \pm 2.3$ & $14.7 \pm 2.7$ & $158.0 \pm 16.5$ & $156.9 \pm 18.3$ \\
\hline $8^{\circ}$ & 36 & $3.30 \pm 0.34$ & $3.22 \pm 0.33$ & $45.3 \pm 6.1$ & $44.1 \pm 5.6$ & $15.6 \pm 2.5$ & $15.5 \pm 2.9$ & $168.0 \pm 14.9$ & $164.5 \pm 16.2$ \\
\hline $9^{\circ}$ & 25 & $3.67 \pm 0.26$ & $3.46 \pm 0.22^{*}$ & $49.5 \pm 4.7$ & $46.8 \pm 5.4^{*}$ & $16.9 \pm 2.1$ & $16.2 \pm 2.8$ & $174.2 \pm 15.7$ & $169.7 \pm 16.2$ \\
\hline $10^{\circ}$ & 15 & $3.92 \pm 0.28$ & $3.73 \pm 0.22 *$ & $51.6 \pm 6.6$ & $49.2 \pm 5.9^{*}$ & $17.6 \pm 2.1$ & $15.8 \pm 2.8^{*}$ & $177.4 \pm 8.9$ & $172.0 \pm 12.4^{*}$ \\
\hline Rest & 42 & $1.29 \pm 0.25$ & $1.27 \pm 0.25$ & $17.7 \pm 3.5$ & $17.4 \pm 3.6$ & $9.0 \pm 2.4$ & $8.2 \pm 2.2^{*}$ & $131.2 \pm 14.5$ & $130.5 \pm 13.5$ \\
\hline
\end{tabular}

Note: $\mathrm{St}=$ stage, $\mathrm{n}=$ number of subjects who completed the stage

$*=p \leq 0.05$

ergometer and was supported by the high consistency of the data $(r>0.89)$. The SEE were similar to the cut-off points established, indicating that $\mathrm{VO}_{2 \mathrm{P}}$ estimated in the cardiopulmonary test performed on the ICBE is accurate when compared to that obtained with the Monark ${ }^{\circledR}$ cycle ergometer.

The kinetics of $\mathrm{VO}_{2} \mathrm{~L} \cdot \mathrm{min}^{-1}$ and $\mathrm{VO}_{2} \mathrm{~mL} \cdot \mathrm{kg}^{-1} \cdot \mathrm{min}^{-1}$ were linear over the load increments for all stages and during recovery. The differences ( $p \leq 0.05 ; \Delta \% 4.7-6.9$ ) in the 3 stages $\left(2^{\text {nd }}, 9^{\text {th }}, 10^{\text {th }}\right.$ ) were lower than the cut-off points established. These differences are not important if the prescription of aerobic resistance training, graded from 10 to $20 \% \mathrm{VO}_{2 \mathrm{P}}$ [6], is considered.

Variations in $\mathrm{VO}_{2}$ of $209 \mathrm{~mL} \cdot \mathrm{min}^{-1}$ and $332 \mathrm{~mL} \cdot \mathrm{min}^{-1}$ for submaximal and maximal loads, respectively, have been observed in repetitive tests on the same cycle ergometer [28]. The difference in $\mathrm{VO}_{2}$ between the ICBE and Monark ${ }^{\circledR}$ bicycle was 80, 210 and $190 \mathrm{~mL} \cdot \mathrm{min}^{-1}$ in the $2^{\text {nd }}$ (submaximal load), $9^{\text {th }}$ and $10^{\text {th }}$ (maximal load) stages, respectively. Thus, the variations in $\mathrm{VO}_{2}$ observed in the present study were markedly lower. This finding is supported by the low mean random error $(\Delta=3.6 \%)$ between the 10 stages. The lower $\mathrm{VO}_{2}$ observed for the ICBE might be explained by the difference in seat tube angle (ICBE: $72^{\circ}$; Monark ${ }^{\circledR}: 80^{\circ}$ ). Larger angles increase power production, alter the posture of the cyclist and reduce activation of the biceps femoralis muscle [24]. The Monark $^{\circledR}$ cycle ergometer probably required greater energy expenditure of the lower limbs, causing a higher $\mathrm{VO}_{2}$ of the accessory muscles and lower economy $[9,23]$. The subjects reported (qualitatively) better pedaling comfort on the ICBE because it is similar to their usual bicycles. In addition, experienced cyclists reduce $\mathrm{VO}_{2}$ when using cycle ergometers with a geometry similar to that of their training bicycles [9,23].

In view of the above considerations and since the differences $(\Delta \%)$ obtained were below the cut-off point established, the ICBE presents concurrent validity for the use in tests quantifying $\mathrm{VO}_{2}$ at submaximal and maximal loads.

$\mathrm{HR}$ and $\mathrm{PE}$ accompanied $\mathrm{VO}_{2}$ kinetics as previously reported $[20,28]$. The difference in HR was $5 \mathrm{bpm}(\Delta=5 \%)$, a difference considered to be poorly relevant [19] and lower than that found in test-retest situations on the same cycle ergometer $(10 \mathrm{bpm}$, $\Delta=10 \%)$ [28]. The small sample size $(n=15)$ might have influenced the differences observed in the $10^{\text {th }}$ stage. The difference of 1.8 points $(\Delta=10 \%)$ in PE is close to the $1.3(\Delta=7 \%)$ reported for maximal loads [28]. HR and PE per se permit to precisely regulate the workload intensity.
Among the 40 comparisons made ( $1^{\text {st }}$ to $10^{\text {th }}$ stage), differences were observed in 8 subjects (20\%), 6 of them (15\%) in the final stages. In clinical practice, this finding does not exclude the use of the ICBE in submaximal and maximal ergometric tests since the physiological, hemodynamic and perceived exertion magnitude $(\Delta \%)$ of these differences is small.

In addition to the factors cited, other factors not analyzed here may contribute to differences between cycle ergometers, such as lack of reliability of the gas analysis system [29]. Cycle ergometer errors and biological variations substantially contribute to common measurement errors [21]. Biological variability accounts for about $90 \%$ of the total variability with $10 \%$ of the remaining variability caused by technical problems [16]. Variations in cadence, incomplete transmission of the load to the wheel [17], internal resistance, chain deformation, and vibration of the load system [10] are some possible sources of cycle ergometer errors. The design and instruments used did not permit to establish the magnitude of these sources of error. This opens the possibility of further studies for the measurement of the power of the ICBE (e.g. direct dynamic calibration) since improvement of the equipment is the most important factor to obtain accurate measures. However, it should be noted that an ergometer presenting validity determined by direct dynamic calibration may not present concurrent validity in relation to a gold standard ergometer because of errors [29] between the same gas analysis systems. However, 5 brands of cycle ergometers were evaluated [7] by comparing the $\mathrm{VO}_{2}$ requirements at different displayed power. Large differences $(5-10 \mathrm{~mL}$. $\mathrm{kg}^{-1} \cdot \mathrm{min}^{-1}$ ) at the same displayed power indicate inaccuracy of displayed power output. Using corrected power values from the standard dynamometer revealed that for the same $\mathrm{VO}_{2}$ the power output was underestimated by $15 \mathrm{~W}$ for the Monark. The researchers [7] did not consider the error of gas analysis systems.

Thus, the results of this study derived from the different statistical analyses permit to infer that the gas analysis system was reliable for the 2 ergometers. Therefore, the ICBE can be used as an ergometer to obtain accurate data.

In conclusion, the hypothesis raised in this study was confirmed, i.e., the subjects presented similar cardiovascular, perceived exertion and hemodynamic responses to exercise on the 2 cycle ergometers. The loads imposed by the ICBE were accurate when compared to the Monark ${ }^{\circledR}$ cycle ergometer. Thus, the ICBE presents concurrent validity for use in submaximal and maximal cardiovascular tests when compared to the Monark ${ }^{\circledR}$ ergometer. 


\section{References}

1 Barbinau C, Leger L, Long A. Variability of maximum oxygen measurement in various metabolic systems. J Strength Cond Res 1999; 13: 318-324

2 Bassett DR, Howley ET, Thompson DL, King GA, Strath SJ, McLaughlin $J E$, Parr BB. Validity of inspiratory and expiratory methods of measuring gas exchange with a computerized system. J Appl Physiol 2001; 91: $218-224$

3 Bland JM, Altman DG. Statistical methods for assessing agreement between two methods for clinical measurement. Lancet 1986; 1: 307-310

4 Burke ER. High Tech Cycling. $2^{\text {nd }}$ ed, Champaign (IL): Humans Kinetics; 2003

5 Caria MA, Tangianu F, Concu A, Crisafulli A, Mameli O. Quantification of Spinning ${ }^{\circledR}$ bike performance during a standard 50 -minutes class. J Sports Sci 2007; 25: 421-429

6 Faria EW, Parker DL, Faria IE. The science of cycling: factors affecting performance - part 2. J Sports Med 2005; 35: 313-337

7 Guiraud T, Léger L, Long A, Thébault N, Tremblay J, Passelergue $P . \mathrm{VO}_{2}$ requirement at different displayed power outputs on five cycle ergometer models: a preliminary study. Br J Sports Med 2010; 44: 449-454

8 Harriss DJ, Atkinson G. International Journal of Sports Medicine - Ethical Standards in Sport and Exercise Science Research. Int J Sport Med 2009; 30: 701-702

9 Heil DP, Derrick TR, Whittlesey S. The relationships between preferred and optimal positioning during submaximal cycle ergometry. Eur J Appl Physiol 1997; 75: 160-165

10 Hibi $N$, Fujinaga $H$, Ishii K. Work and power outputs determined from pedalling and flywheel friction forces during brief maximal exertion on a cycle ergometer. Eur J Appl Physiol 1996; 74: 435-442

11 Hilloskopi H, Manttari A, Pasanen M. The comparison between three different respiratory gas analysers. Med Sci Sports Exerc 2000; 31: S354

12 Hodges $L D$, Brodie DA, Bromley PD. Validity and reliability of select commercially available metabolic analyzer systems. Scand J Med Sci Sports 2005; 15: 271-279

13 Iscoe KE, Campbell EJ, Jamnik V, Perkins B, Riddell M. Efficacy of continuous real-time blood glucose monitoring during and after prolonged high-intensity cycling exercise: spinning with a continuous glucose monitoring system. Diabetes Technol Ther 2006; 8: 627-635

14 Kang J, Chaloupka EC, Mastrangelo MA, Hoffman JR, Ratamess NA, O'Connor E. Metabolic and perceptual responses during spinning ${ }^{\circledR}$ cycle exercise. Med Sci Sports Exerc 2005; 37: 853-859

15 Lucia A, Balmer J, Davison RCR, Pérez M, Santalla A, Smith PM. Effects of the rotor pedaling system on the performance of trained cyclists during incremental and constant-load cycle-ergometer tests. Int Sports Med 2004; 25: 479-485
16 MacFarlane D. Automated metabolic gas analysis systems: a review. Sports Med 2001; 31: 841-861

17 MacIntosh BR, Bryan SN, Rishang P, Norris SR. Evaluation of Monark Wingate ergometer by direct measurement of resistance and velocity. Can J Appl Physiol 2001; 26: 543-558

18 Marsh AP, Martin PE, Foley KO. Effect of cadence, cycling experience, and aerobic power on delta efficiency during cycling. Med Sci Sports Exerc 2000; 32: 1630-1634

19 Neder JA, Stein R. A simplified strategy for the estimation of the exercise ventilatory thresholds. Med Sci Sports Exerc 2006; 38: 1007-1013

20 Noble BJ, Robertson RJ. Perceived Exertion. Champaign (IL): Human Kinetics; 1996

21 Paton $C D$, Hopkins $W H$. Ergometer error and biological variation in power output in a performance test with three cycle ergometers. Int J Sports Med 2006; 27: 444-447

22 Petroski EL, Glaner MF, Pires-Neto CS. Equations for estimating body composition of Brazilians. In: Petroski EL, Pires-Neto CS, Glaner MF (eds). Biométrica. Jundiaí: Fontoura; 2010; 249-268

23 Reiser M, Meyer T, Kindermann W, Daugs R. Transferability of workload measurements between three different types of ergometer. Eur J Appl Physiol 2000; 82: 245-249

24 Ricard MD, Hills-Meyer P, Miller MG, Michael TJ. The effects of bicycle frame geometry on muscle activation and power during a Wingate anaerobic test. J Sports Sci Med 2006; 5: 25-32

25 Silva RAS. Development and calibration of an indoor cycling bicycle with load graduation. Braz J Kinanthropom Hum Performance [Internet]. Available from: http://www.periodicos.ufsc.br.br/index.php/ rbcdh/article/view/3880/401/1 2006, [cited 2006 Jul 31]; 8 (2)

26 Siri WE. Body composition from fluid spaces and density: analysis of methods. In: Brozek J, Henschel A (eds). Techniques for Measuring Body Composition. Washington (DC): National Academy of Sciences, National Research Council; 1961; 223-244

27 Von Döbeln W. A simple bicycle ergometer. J Appl Physiol 1954; 7: 222-224

28 Wergel-Kolmert $U$, Wisén A, Wohlfart B. Repeatability of measurements of oxygen consumption, heart rate and Borg's scale in men during ergometer cycling. Clin Physiol Funct Imaging 2002; 22: 261-265

29 Yule E, Kaminsky LA, Sedlock DA, King BA, Whaley MH. Inter-laboratory reliability of $\mathrm{VO}_{2 \max }$ and sub maximal measurements. Med Sci Sports Exerc 1996; 28: S15 